\title{
SUPPLY CHAIN OF SUBSIDIZED CHEMICAL FERTILIZERS IN NEPAL
}

\author{
H.K. Panta* \\ Institute of Agriculture and Animal Science, Tribhuvan University, Nepal \\ *haripanta@yahoo.com
}

\begin{abstract}
A survey was conducted with different supply chain actors of chemical fertilizers for studying the supply chain of chemical fertilizers in Nepal in 2018. Chemical fertilizers in Nepal are imported from different manufacturing countries like Turkey, China, Egypt and India by global tender and by government to government negotiation especially from India. Potential demand for fertilizer in Nepal is about 7,00,000 MT of which actual supply in the year 2016/17 was $3,24,977$ MT. Average subsidy on chemical fertilizer in Nepal since 2008/09 is estimated to be NRs. 3,73,42,27,780 (43.78\%). Procurement, shipping, warehousing at port, inland transportation, inland warehousing, local transportation, distribution and consumption are major supply chain functions of chemical fertilizer specific to Nepal. Final sell price of urea, DAP and MOP in Sindhupalchhok in the year 2016 was found 37, 15 and 23\% respectively higher than entry point sell price. Non-conducive policy environment, ineffective regulation, lack of fund and poor infrastructure are major problems of fertilizer supply in Nepal. Illegal trading from open border of India and selling of subsidized fertilizers by unauthorized agro-dealers are other problems of this sector.Though government has been investing large revenue in fertilizer subsidy, expected results in productivity enhancement has not been met. Assured supply of quality fertilizer in time is more important even than the price of fertilizer. Therefore, emphasis is to be led on implementation of conducive policy, strict regulation and infrastructure development focusing on timely supply, judicious application, checking illegal trading along with the promotion of use of organic manures.
\end{abstract}

Key Words: Chemical Fertilizer, Supply Chain, Subsidy, Illegal trading

\section{INTRODUCTION}

Nepalese economy is predominantly agriculture based and the agriculture sector contributes to approximately one third of Gross Domestic Product (GDP). Agriculture is the main source of livelihood of about two-third population of the country. Since, average size of the agricultural land is 0.7 ha and holdings operating less than 0.5 ha are $51.6 \%$ (CBS, 2014), increased productivity is utmost necessary to feed ever increasing population of the country. With commercialization of agriculture, demand for agro-chemicals has been continually increasing. Chemical fertilizer is the most important agricultural input which unavailability in time and required quantity hampers crop production to great extent.

Fertilizer supply remains critically below itsdemand in Nepal. The state-owned Agriculture Inputs Company Limited (AICL) and the public corporation Salt Trading Corporation Limited (STCL) have not been able to achieve timely, sufficient and profitable fertilizer supply and distribution. During deregulation as the private sector cannot compete well with smuggled fertilizer (which is of lower cost due to India's subsidy) when there is high price differential between Nepal and India. During this time, a substantial amount of fertilizer is imported illegally, much of which is adulterated (ADS, 2014).

According to NEAT (2014), in 2011/12 potential demand for chemical fertilizer in Nepal was about 700,000-800,000 MT. However, the effective demand was 500,000 MT of which formal sector 
supplied only 75,000 MT and the rest was supplied by informal sources including small private traders. Previous data shows that, from 2001/02 to 2008/09 both AICL and private trader's supply of chemical fertilizer in Nepal was highly fluctuating year after year which later on showed continuous increment up to 2013/14 (MOAD, 2014).

ADS (2014) explained that policy needs revision to include private sector in fertilizer supply to meet its demand in Nepal. It further stated that if fertilizer smuggling is not controlled, it prevents government and legal private sector from efficiently supplying the required amount of fertilizer. UNDP's study revealed that 86 percent of farmers recognize AICL fertilizer as good. However, the quality of fertilizer that farmers purchased from unregistered dealers and other informal sources was of average quality or not considered satisfactory.

NEAT (2012) reported that price was not a determining factor for fertilizer use in Nepal. Household characteristics are important factors affecting fertilizer use than price. Based on study findings, NEAT recommended the improvement in soil management to improve the effectiveness of fertilizer used by farmers. Similarly, addressing the issue of informal supply, minimizing the use of poor quality fertilizers and decreasing the risk involved with informal supply of fertilizer from India by increasing the availability of formal fertilizer are key issues in solving fertilizers related problems in the country.

Fertilizer prices and trade in Nepal are much more dominated by illegal imports from India. If Nepal is able to formalize the informal trade, it would reduce illegal activities and improve fertilizer supply and use, both in Nepal and India. For food and fertilizer security, Nepal should also invest in fertilizer production in India (NEAT, 2014).

Government has formulated numbers of policies, orders and directives such as Chemical Fertilizer Control Orders 1998, Chemical Fertilizer Directives 2000, The National Fertilizer Policy 2002, National Fertilizer Policy Revisited 2009 and many others to regulate fertilizer use and increase productivity in the country. However, fertilizer policy in Nepal has focused on supplying high-quality and affordable fertilizer to farmers. Unfortunately, over the years, this policy has led to an imbalanced use of crop nutrients, often over use of nitrogen while under use of other macronutrients, secondary nutrients and micronutrients. In the past, Nepal fertilizer policy was focused primarily on fertilizer supply rather than fertilizer demand, which has led to an imbalance of available crop nutrients.

In recent years, international fertilizer prices have risen high. Since 2001/02 average sales price of Urea, Di-ammonium Phosphate (DAP) and Murate of Potash (MOP) have increased almost double. According to economic survey conducted by AICL in the year 2013/14 prices of these fertilizers were Rs. 18, 45 and 32 per kg respectively (MOAD, 2014). In addition, sea freight, port clearance and the cost of transportation from the Kolkata port have all risen. Private traders reported that the cost of transporting fertilizer from the port in Kolkata to Nepal can account for as much as $20 \%$ of the cost of delivered fertilizer. On the other hand, the Nepalese currency has devaluated steadily against the US dollar. As a result, fertilizer prices in Nepal are very high. This scenario has encouraged market actors to bring in large volumes of illegally imported, highly subsidized fertilizer from India.

Twenty-years' APP has identified chemical fertilizer as an engine of agricultural growth. Fertilizer is expected to contribute 64 to $75 \%$ of the total envisaged agriculture growth target of APP. APP has targeted an increase in fertilizer use from $31 \mathrm{~kg}$ nutrient/ ha of the base year 1995 to $131 \mathrm{~kg}$ nutrient/ ha by 2017 (Shrestha, 2010).

According to Takeshima et al. (2016) the nutrients from fertilizing with manure seem to substitute for chemical fertilizer use in Nepal. This howeveris contradictory to findings from other countries; for example, in Niger these two were complementing each other (Abdoulaye and Sanders, 
2005).The price responsiveness of chemical fertilizer use in Hills of Nepal is low because of low returns to chemical fertilizer use. They suggested that policies aimed at increasing the use of chemical fertilizer in Nepal, particularly in the Hills and the Mountains, may need to focus on raising returns from chemical fertilizer instead of on reducing the price of chemical fertilizer through subsidies.

Fertilizer price has insignificant effect in real per capita income and real per capita agricultural income. On the other hand, the effects of chemical fertilizer prices on per capita crop revenues are generally insignificant across all farm sizes. Lower chemical fertilizer price leads to greater increases in per capita agricultural revenues or incomes for larger farms than smaller farms (Takeshima et al., 2016).

Supply of essential chemical fertilizer in Nepal is far below the total demand at present. Farmers are not getting chemical fertilizers in time and have to pay higher price to them. Past studied clearly indicated that the fertilizer supplied by the informal sources are of poor quality. Further, illegal trading of inorganic fertilizers especially from India is resulting into poor national income and supply of low quality fertilizer suffering the farmers. Thus, study on supply chain of chemical fertilizer along with its price formation may help to provide farmers the high quality fertilizer in required quantity, in time and at affordable price. Findings of the study will be useful to improve the fertilizer supply situation in the country. In this regard, the broad objective of this study was to study the supply chain of subsidized chemical fertilizer in Nepal whereas, the study specifically aimed to:

1. analyze the trend of chemical fertilizer use is world as well as in Nepal

2. study the conduct and performance of fertilizer supply chain and price formation of subsidized fertilizer in Nepal

3. assess the problems of fertilizer procurement and distribution in Nepal

\section{METHODOLOGY}

\section{Study site}

This study covered specific sites of fertilizer procurement, distribution and use in Nepal. Study area includes three important custom offices of Nepal viz., Biratnagar, Birjung and Bhairahawa. Sites of fertilizer importing as well as distributing agencies like private sector traders and government or semi-government agencies like AICL, STCL and their distribution sites as well as cooperatives and farmers from Sindhupalchhok, Dhading, Gorkha, Chitwan and Rupandehidistricts represent the study area.

\section{Data collection methods}

Diversified methods of data collection were employed for successful completion of this survey research. Major data collection methods were as follows:

Key Informant Interview:- Interview was done with officials working in three major custom offices as mentioned above to obtain information on custom and import of major fertilizers. Similarly, AICL and STCL representatives were interviewed to get data on trend of fertilizer import, distribution and pricing systems and problems faced by the organization. MOAD and SMD officials were interviewed to be aware about policies and data on chemical and organic fertilizer procurement and sell in Nepal. In addition 10 input dealers (5 wholesalers and 5 retailers) as well as one agricultural cooperative in Sindhupalchhok district were interviewed for data on volume of sell, margins and their attitude towards the supply system and policy related to fertilizer sub-sector in Nepal. Appropriate check lists were administered for this purpose. 
Focus Group Discussion:- One group discussion was done with cooperative members and progressive farmers in the study district to study their attitude and knowledge on supply system of fertilizer in Nepal. The group discussion also identified the major fertilizer related problems of the district. A group discussion module was prepared and used for collection of information by this method.

\section{Sources of Data}

Both primary and secondary data were collected for the attainment of research objectives. However, the study basically relied on secondary data on fertilizer import and distribution. Information obtained from household survey, KII and FGD constituted primary sources and that obtained from printed as well as electronic sources (published and/or unpublished) served as the secondary sources. Secondary data were basically collected to analyze fertilizer demand and supply situation, price and trends of their use in the country.

\section{Data analysis methods}

Collected information were processed, validated and analyzed basically by using Microsoft EXCEL. Following analyses will be done for the accomplishment of the research objectives:

Trend analysis: Extensive analysis for fertilizer use and import trend as well as price trend in the country werebe done by using time series data.

Supply chain conduct and performance analysis: Fertilizer supply chain conduct and performance were analyzed with the help of appropriate diagrams.

Fertilizer price formation assessment: Price formation of all types of subsidized chemical fertilizers was assessed with the help of tables and graphs.

Descriptive statistics like percentage and mean were extensively employed to analyze data obtained from each level. Tables and graphs were used to present data as per need and suitability. Similarly, flow diagrams and pictures were used to show supply chain.

\section{RESULTS AND DISCUSSION}

\section{World fertilizer trend}

World fertilizer nutrient $\left(\mathrm{N}+\mathrm{P}_{2} \mathrm{O}_{5}+\mathrm{K}_{2} \mathrm{O}\right)$ consumption is estimated as 184.67 million tonnes in 2014 which will reach 186.6 million tonnes in 2015 , up by $1.1 \%$ over 2014 . World demand for total fertilizer nutrients is estimated to grow at 1.6 percent per annum from 2015 to 2019 (will be 199 million tonnes). The demand for nitrogen, phosphate, and potash is forecast to grow annually by 1.2 , 2.0 and $2.5 \%$, respectively, during the period. Over the next five years, the global capacity of fertilizer products, intermediates and raw materials will increase further. The global total nutrient capacity $\left(\mathrm{N}+\mathrm{P}_{2} \mathrm{O}_{5}+\mathrm{K}_{2} \mathrm{O}\right)$ was 284 million tonnes in 2014 , out of which the total supply was 240 million tonnes. During 2015 , the total capacity is expected to increase by 2.9 percent and supply would grow by 1.6 percent. Over the next five years, global capacity and production of fertilizers would increase further. South Asia and Latin America/Caribbean will be in completely negative balance whereas, eastern Europe/central Asia and east Asia in positive balance (USAID, 2014).

\section{Chemical fertilizer supply in Nepal}

AIC, as a public sector enterprise, had a monopoly in fertilizer trade for a long time before the government decided to deregulate the fertilizer trade in 1997-98. Prior to this time, the AIC had full control for procurement and distribution of fertilizers. In addition, the sale prices of fertilizers were 
regulated by the government. Again in 2009, subsidized fertilizer was imported and distributed only by AIC. This resulted in significant market changes. As of 2013, the retail fertilizer price for farmers through the AICL was set at 20-25\% above Indian prices at the border, plus the cost of transportation. After the re-establishment of the subsidy, fertilizer import has increased visibly. However, it still only provides about $20 \%$ of the country's total demand for fertilizer. Under this policy change, the private traders limited imports of NPK fertilizers because they could not compete with the subsidized fertilizers (NEAT, 2012). Role of private sector seemed important during deregulation period. Private sectors' supply seemed very high compared to public sector supply in each year of this period.

From a recent farm-level survey, fertilizer use exceeds 700,000 MT at present. Fertilizer use is projected to increase to 1,500,000 MT in 2022. Actual supply of all fertilizer products (Urea, DAP and MOP) in the year 2001/02 was estimated to be 140766 MT which reached to 259062 MT in the year 2015/16 (Table 1).

Table 1: Trend of chemical fertilizer distribution by public and private sector in Nepal (2001/022015/16)

\begin{tabular}{|c|c|c|c|c|}
\hline Year & AICL/STCL & Private sector & Total & Remarks \\
\hline $2001 / 02$ & 39358 & 101408 & 140766 & \multirow{12}{*}{ 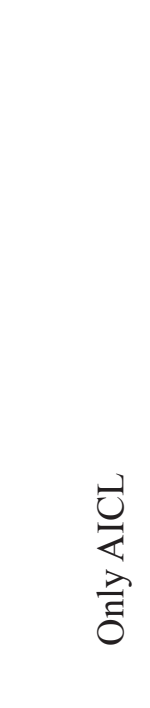 } \\
\hline $2002 / 03$ & 70746 & 103636 & 174382 & \\
\hline $2003 / 04$ & 20493 & 118265 & 138758 & \\
\hline $2004 / 05$ & 31811 & 90895 & 122706 & \\
\hline $2005 / 06$ & 13295 & 78258 & 91553 & \\
\hline $2006 / 07$ & 25169 & 65679 & 90848 & \\
\hline $2007 / 08$ & 6646 & 47107 & 53753 & \\
\hline $2008 / 09$ & 7133 & 5677 & 12810 & \\
\hline $2009 / 10$ & 103289 & NA & 103289 & \\
\hline $2010 / 11$ & 110013 & NA & 110013 & \\
\hline $2011 / 12$ & 144814 & NA & 144814 & \\
\hline $2012 / 13$ & 176963 & NA & 176963 & \\
\hline 2013/14 & 232189 & NA & 232189 & \multirow{3}{*}{ 尝 } \\
\hline $2014 / 15$ & 298874 & NA & 298874 & \\
\hline $2015 / 16$ & 259062 & NA & 259062 & \\
\hline
\end{tabular}

Source: $M O A D, 2016$

There is continuous increase in fertilizer sell by AICL and STCL after 2009's subsidy regulation despite the sudden fall in 2015/16 than the preceding year. However, the total import was not less in that year compared to 2014/15 (Table 2). 


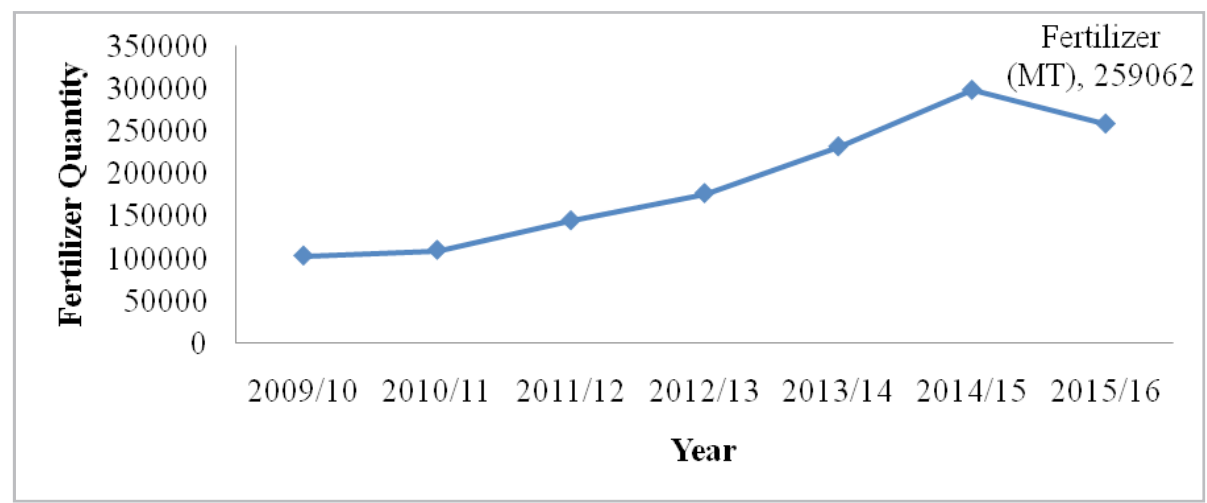

Figure 1: Trend of fertilizer supply by AICL and STCL in Nepal (2009/10-2015/16)

Figure 1 has given the clear indication of ever increasing demand of chemical fertilizer in Nepal. As private traders almost stopped procuring fertilizers on which there is subsidy and the sole responsibility rested on these two organizations and their transactions increased significantly during this period (Figure 1)

\section{Subsidy in chemical fertilizer in Nepal}

With the restoration of subsidy policy in the year 2009, fertilizer import and sell in Nepal has been continuously increased. During the period 2008/09 to 2016/17, about 39 to 58 percent subsidy was provided on their procurement. The subsidy on an average during this period was estimated to be $43.78 \%$ in which the government's total investment was NRs. 33,60,80,50,017. The average annual investment of the government during this nine year period was found to be NRs. 3,73,42,27,780.

Table 2: Fertilizer import, sell and subsidy in Nepal (2008/09-2016/17)

\begin{tabular}{llllll}
\hline Year & Import (MT) & Cost ('000 Rs) & Sell (MT) & Subsidy (Rs) & Subsidy (\%) \\
\hline $2008 / 9$ & 22484 & 688087 & 7090 & 366812126 & 53.30 \\
$2009 / 10$ & 81594 & 2819139 & 81845 & 1370518260 & 48.61 \\
$2010 / 11$ & 149907 & 6195372 & 110031 & 2526380818 & 40.78 \\
$2011 / 12$ & 112126 & 5415758 & 144813 & 3129947630 & 57.79 \\
$2012 / 13$ & 220544 & 11468933 & 176963 & 5171837181 & 45.09 \\
$2013 / 14$ & 273239 & 12786106 & 232879 & 5308772649 & 41.51 \\
$2014 / 15$ & 281000 & 12919793 & 298677 & 5324806353 & 41.21 \\
$2015 / 16$ & 287430 & 12236820 & 259061 & 5665075000 & 46.30 \\
$2016 / 17$ & 307771 & 12238376 & 324977 & 4743900000 & 38.76 \\
Total & 1736095 & 76768384 & 1636336 & 33608050017 & 43.78 \\
\hline
\end{tabular}

Note: Subsidy percent is the percent of total cost

Source: MOALD, 2018

\section{Supply chain map of chemical fertilizer in Nepal}

Planning, input supply, manufacturing, delivery and purchase of final product are the major functions of fertilizer supply chain in general. GON, MOAD, line ministries, cooperatives, private sectors, I/NGOs and public private partnership organizations are the major stakeholders involved in 
planning of fertilizer sub-sector. Suppliers, manufacturers, warehouse and distribution agencies and customers are the key actors of the supply chain. Cooperatives and agro-vets are operating as the lower level distributors of chemical fertilizer in the country. However, the subsidized fertilizers are distributed only by the cooperatives who receive the fertilizer from nearby depots of the AICL and STCL. STCL and AICL imports fertilizer and ask tender for internal transportation from the port of importation to their sells depots. Government provides lump sum subsidy to these organizations which is refunded upon submission of bills to MOALD by them.

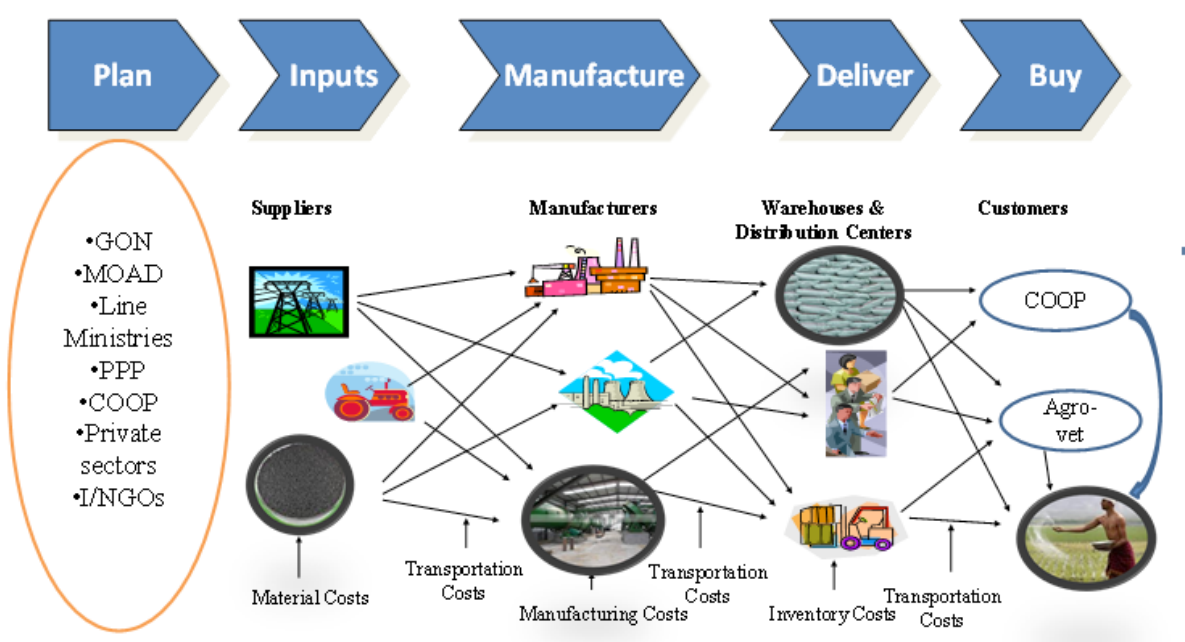

Figure 2: General supply chain of chemical fertilizer in Nepal

\section{The Fertilizer Supply Chain Stakeholders in Nepal Global Market}

Major global market supply chain stakeholders of chemical fertilizers in Nepal are manufacturers and traders (supply fertilizers); shipping companies (responsible for shipping products), inspection agencies (ensures truth in labeling) \& banks (provide credit).

\section{Domestic Market}

- The domestic market supply chain stakeholdersof fertilizer sub-sector in Nepal are:

- Policy makers - GON/MOAD and line ministries, DADO (district level)

- Importers - AICL, STCL and private sector traders

- Transporters - private transporters

- Banks and cooperatives - credit supply

- Port authorities, warehouse and regulators - store, enforce quality standards

- Distributors: AICL/STCL, coop, agro-vets (wholesalers- sell fertilizer in large quantities to retailers or large farmers; and retailers - sell fertilizer to small and medium farmers)

- Farmers- use fertilizer on different crops

At present Nepal (AICL and STCL) imports fertilizer from Turkey, Peoples Republic of China, Egypt, and India. AICL and STCL invite sealed tenders for the supply of fertilizer by publishing global tender notice in the reputed national newspaper. Invitation of global tender is based on seasonal demand. Beside global tender, AICL is also importing fertilizer from India on government to government basis on Import Parity Price (IPP) of India. They also procure as directed by the 
government fertilizer received on grant/aid by the donor government as buffer stocks and distribute it. According to Nepal Rastra Bank (2016) China remains the largest supplier of chemical fertilizers to Nepal in the first 10 months of the fiscal year 2015/16. Its import from India, traditionally its biggest supplier, has been decreasing in recent years. Although Indian fertilizers had a predominant presence in Nepal's fertilizer market until fiscal year 2013-14, China has emerged as the largest supplier in fiscal year 2014-15 and moved on to remain the largest supplier as of the first 10 months of the current fiscal year too.

\section{Fertilizer supply chain: conduct and performances}

Fertilizer supply chain conduct covers procurement by global tender or GTG negotiation from overseas fertilizer manufacturers; ocean freight in international shipping; unloading, bagging, inspection, customs and taxes in Nepalese port; local transport, unloading and storage during warehousing at port, inland transportation; inland warehousing; local transportation; retail sells by cooperatives and agrovets and consumption by farmers. Cost components consists of FOB cost, freight cost, port charges and taxes, warehouse cost (warehouse at port and inland warehouse), transport cost (inland and local transportation) and other operating costs like storage cost, load and unload cost, finance, overhead, bagging, commission and margins. Supply chain conduct and performances of chemical fertilizer is shown in section 1, 2 and 3 of figure 3.
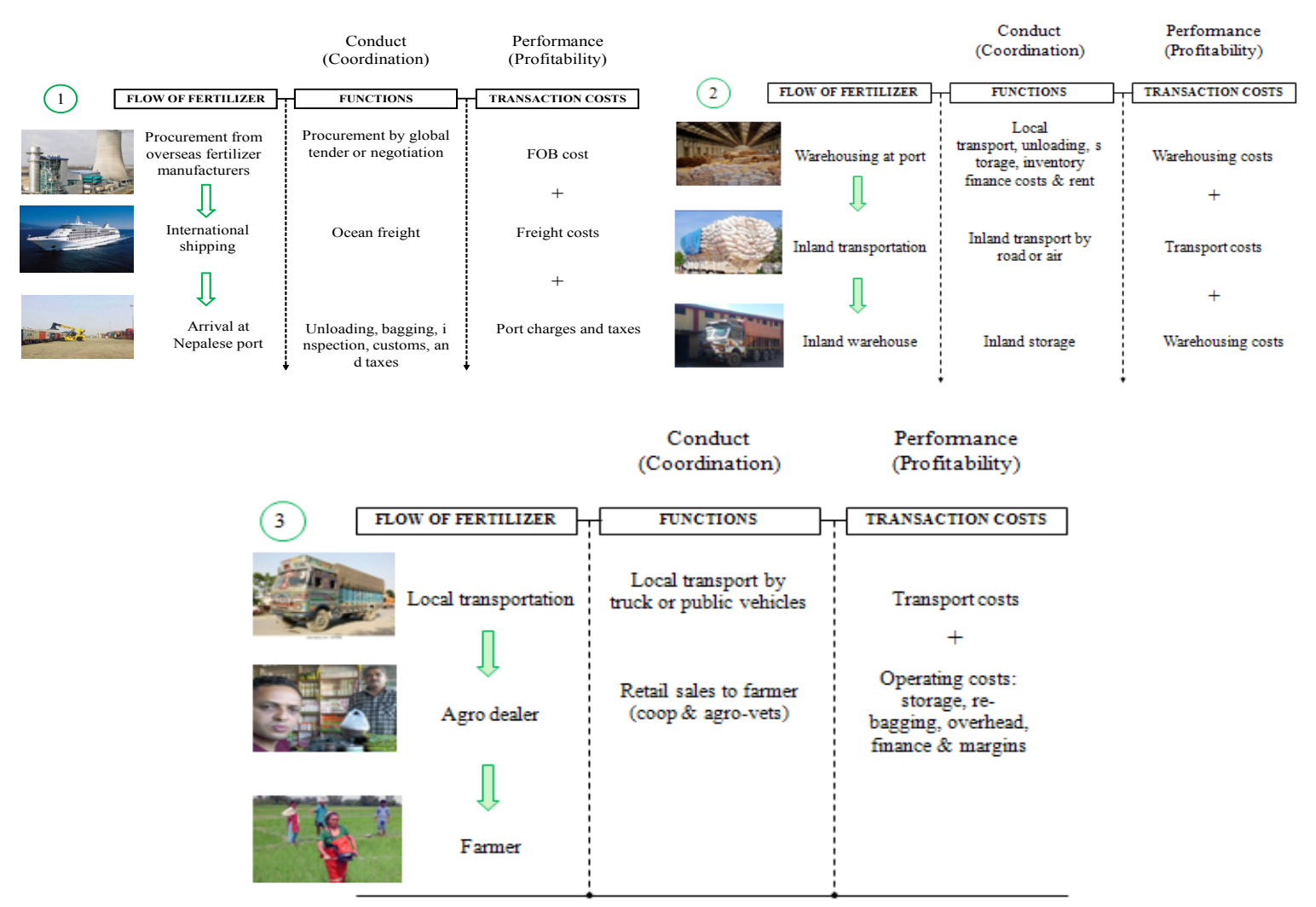

Figure 3: Conduct and performances of fertilizer supply chain in Nepal

\section{Flow chart of fertilizer supply system in Nepal}

Flow chart of supply system of chemical fertilizer in Nepal is shown in figure 4. Major activities in the system are import, pricing transportation and distribution. Fertilizer in Nepal is imported by 
global tender or GTG negotiation. It enters into the country mainly from Birjung, Biratnagar and Bhairahawa. The sell price is fixed in entry point which is set by deducing subsidy from purchase price (cost price). AICL and STCL do branch wise tender for domestic transportation and DADO bears transportation cost in the districts which are provided the transportation subsidy. AICL and STCL distributed subsidized fertilizers through their depots. Government provides NRs. 250 commission to the cooperatives per ton of all fertilizer products. Finally cooperatives sell the fertilizer to the farmers adding local transportation cost on their purchase price from AICL and STCL depots.

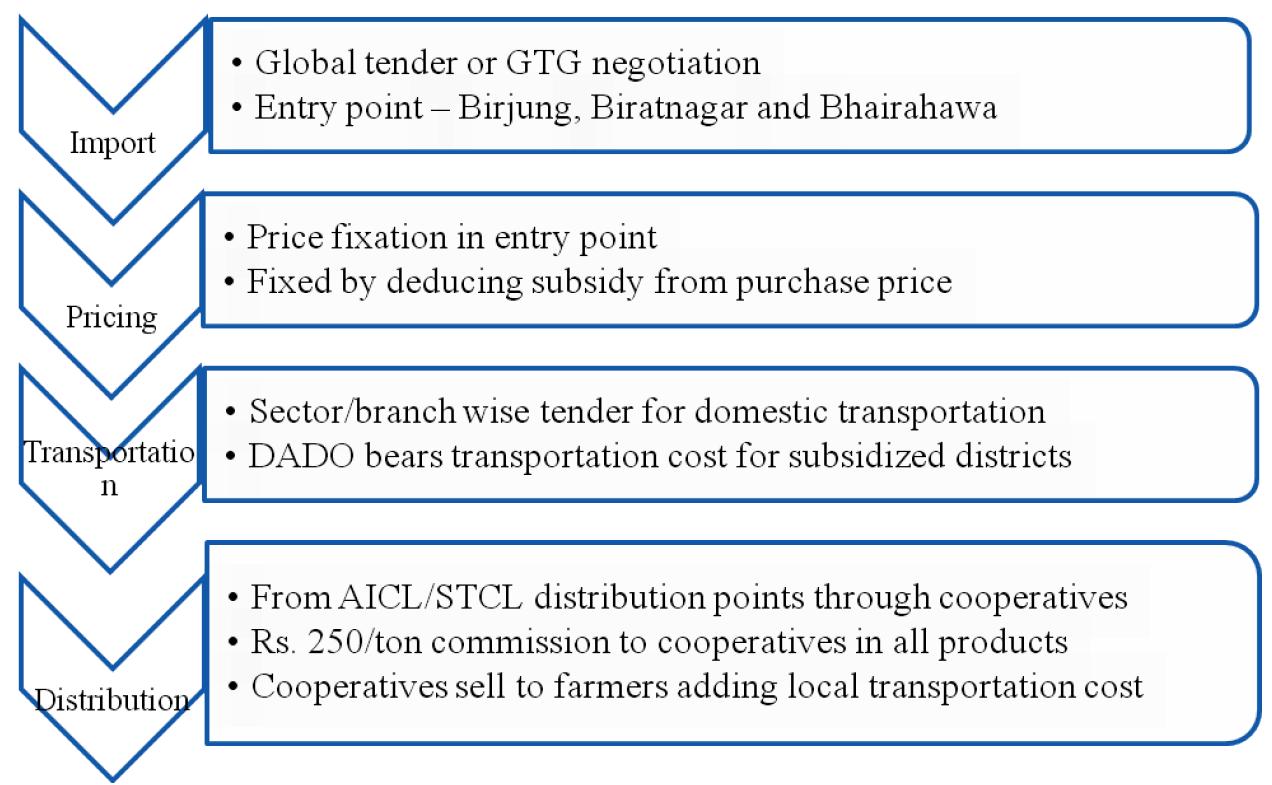

Figure 4: Flow chart of supply system of subsidized chemical fertilizer in Nepal

\section{Price formation of chemical fertilizer in Nepal}

During survey, the entry point sell price of Urea, DAP and MOP at Bhairahawa for a lot imported during 2016 was found to be NRs. 900, 2250 and 1550 per $50 \mathrm{~kg}$ respectively. Adding transportation cost and commission for cooperatives, sell price in Sindhupalchhok was NRs. 1230, 2580 and 1900 respectively for these products. It indicated that final sell prices at cooperatives in Sindhupalchhok for urea, DAP and MOP were 36.7\%, 14.7\% and 22.6\% higher over entry point sell price of these products respectively (Figure 5). Since fertilizer price in global market fluctuates time and again because of manufacture cost, USD worth and other political factors, it affects importation cost resulting into fertilizer price in Nepal also. Therefore, lot by lot variation in price of chemical fertilizer prevails in Nepal. It is also affected by the local transportation cost which keep on changing time and again for different lots. 


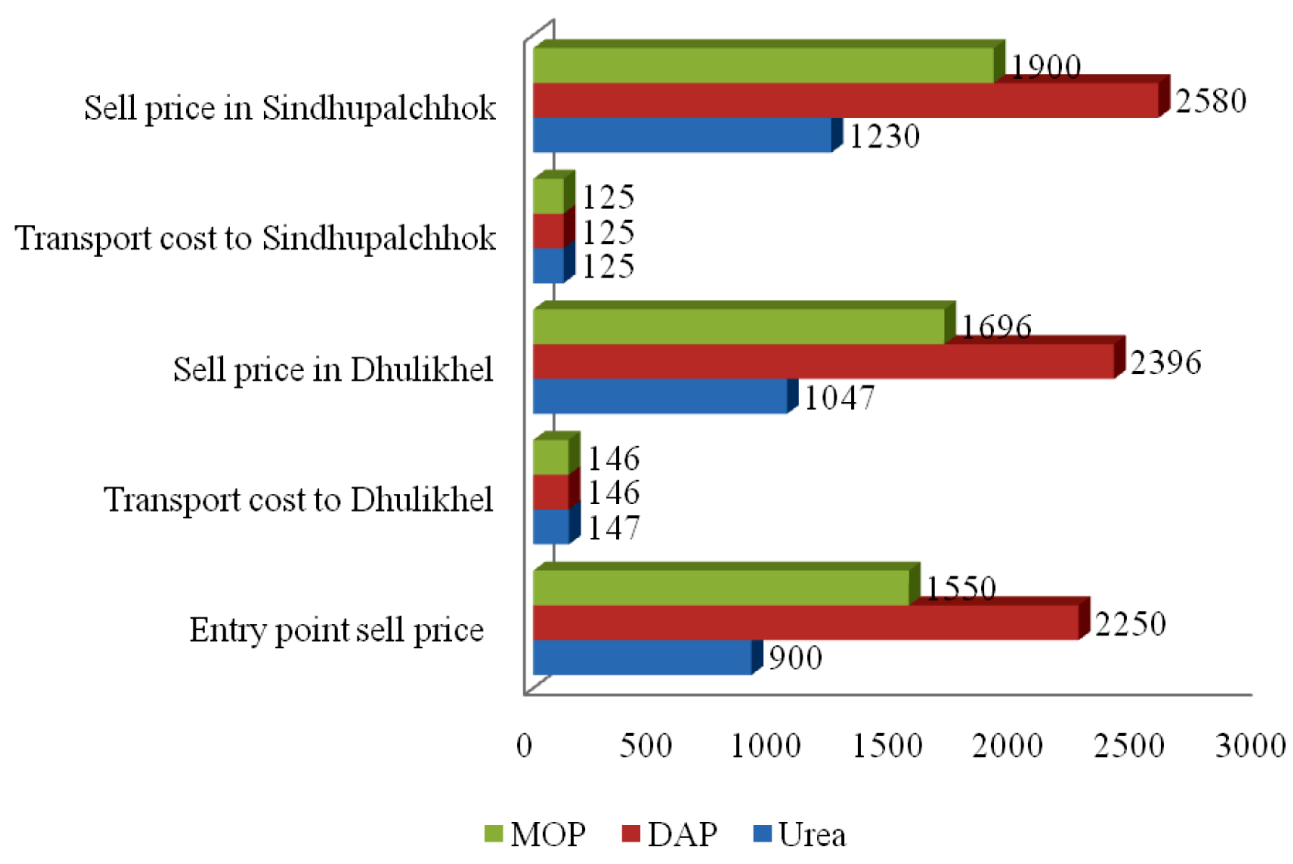

Problems of fertilizer supply system in Nepal

Non-conducive policy environment

- Unstable price inducing uncertainties

- No enough focus on timely supply and quality

- Subsidy on organic fertilizer ineffective

- Failure to check illegal cross-boarder transaction

- Discouragement of private traders due to subsidy

- Non-participatory policy making (MOAD only, no involvement of other chain actors)

- Unhealthy competition and dispute between AICL and STCL

- Area limitation for hills and terai is not scientific

- More focus on subsidy rather than quality and timely supply of chemical fertilizer

- Only coops are mandated to sell subsidized fertilizers

- Poor technical knowledge among cooperative operators

- Lack of fund - private dealers taking subsidized fertilizers with the name of cooperatives and give Rs. 50/sac commission to cooperatives

- Majority of cooperatives are located in inaccessible area

- Irregular supply (main season only) - cooperative do not supply fertilizer throughout the year

- Most of the cooperatives are not operating under strict cooperative rules - selling fertilizers to retail shops in higher prices - farmers are paying higher prices to them

\section{Ineffective regulation}

- Poor enforcement of quality control standards at the point of sale due to limited human capacity of ministry and department 


\section{Lack of fund}

- Cooperatives lacks sufficient fund there is difficulty in borrowing (needs collateral), similarly high interest rate on loan

\section{Inadequate human capital}

- Limited skilled manpower for imports and marketing

- Poor knowledge base of cooperative members regarding fertilizers' attributes

\section{Restricted multi-country trade}

- Tariff and not-tariff restrictions on multi-country trade

\section{Inadequate market transparency \& business linkages}

Agro-vets are selling subsidized fertilized (not mandated)

\section{Poor infrastructure}

- Inefficient port handling facilities

- Inadequate warehouse facilities

- Underdeveloped road linkage

\section{Others}

- It takes too long time to bring fertilizer by global tender (5-6 months)

- As exchange rate of USD unstable (raised high during long course of time) - supplier give up the tender deposit - farmers don't get fertilizer

- Labour strike in ports

\section{CONCLUSION}

For increased agricultural productivity assured supply of quality fertilizer in time and affordable price is utmost necessary. However, present supply of chemical fertilizer in Nepal is not meeting its demand. In this contest, government and importing organizations must lay focus on timely supply even more than to subsidy. Though, very large amount of government fund is being invested in fertilizer procurement for subsidy, expected results in terms of agricultural production and productivity have not been met. Alternatives like improvement of FYM and promotion of organic production may save considerable revenue, maintain soil and human health. Efforts should be put on checking illegal trading and distribution of subsidized fertilizers by unauthorized dealers or they should be mandated. Non-conducive policy environment, weak regulation, poor infrastructure, inadequate fund and human resources are major fertilizer related problems in Nepal. Therefore, government should invest in infrastructure as well as human resource development.

\section{ACKNOWLEDGEMENT}

Officials from MOALD, DOA, AICL, and STCL in Kathmandu and sells depots of AICL as well as STCL operating in different parts of country are highly acknowledged for providing necessary information valuable for the study. Similarly, I would like to extend my sincere thanks to key informants from cooperatives, agro-vets and others visited during the survey. I am also thankful to the University Grant Commission (UGC) for providing research grant. My sincere thanks also go to IAAS for Ph.D. opportunity and kind cooperation throughout the study. Finally I am grateful to Dr. Punya Prasad Regmi, Dr. Gopal Bahadur K.C., Dr. Devendra Gauchan and Dr. Hum Nath Bhandari who have provided me crucial guidelines in the course of my study. 


\section{REFERENCES CITED}

Abdoulaye, T., \&Sanders, J.H. (2005). "Stages and Determinants of Fertilizer Use in Semiarid African Agriculture: The Niger Experience.” Agricultural Economics 32 (2): 167-179.

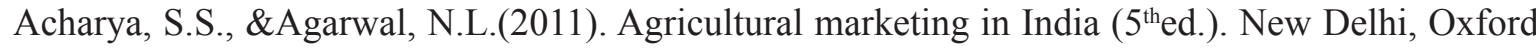
and IB H Publishing Co. Pvt. Ltd.

ADS, 2014.Agriculture Development Strategy (ADS).Ministry of Agriculture Development. Singhadurbar, Kathmandu, Nepal.

AICL.(2016). Agriculture Input Company Limited (AICL).Government of Nepal. Available: http:// www.aicl.org.np/english/home/news_events-news.php. Retrived: January 1, 2016.

MoAD.(2014). Statistical information on Nepalese agriculture, 2013/14.Ministry of Agricultural Development (MoAD), Agri-business Promotion and Statistics Division (ABPSD), Singhadurbar, Kathmandu, Nepal.

NAP.(2004). National Agricultural Policy, 2004.Government of Nepal. Available: www. lawcommission.gov.np. Retrieved: January 5, 2016.

NEAT.(2012). Nepal Fertilizer Demand and Plant Nutrient Assessment, a Study commission by USAID on behalf of ADS.Nepal Economic, Agriculture and Trade Activity (NEAT).

NRB. (2016). China remains the largest supplier of chemical fertilizer to Nepal. http://www.chinadaily. com.cn/business//2016-06/23/content_25825272.htm [Retrived 6th February, 2018]

Shrestha, R.K. (2010). Fertilizer policy development in Nepal.The journal of agriculture and environment. 11: 126-137.

Supply Chain Definition Investopediahttp://www.investopedia.com/terms/s/supplychain. asp\#ixzz4IE3LHfF9. [Retrived $28^{\text {th }}$ August 2016].

Takeshima, H., Adhikari, R.P., Kaphle, B.D., Shivakoti, S., \& Kumar, A. (2016). Determinants of chemical fertilizer use in Nepal.Inshight based on price responsiveness and income effect. IFPRI discussion paper 01507. International Food Policy Research Institute (IFRI).

Takeshima, H., Shivakoti, S., Bhattarai, B., Karkee, M., Pokharel, S., and Kumar, A. (2016). Farm size and effects of chemical fertilizer price on farm households. Insights from Nepal Terai. IFPRI discussion paper 01578. International Food Policy Research Institute (IFPRI).

USAID. (2014). Regional trade in seed, fertilizer and strategic grains: A Review of the Legal, Regulatory, and Institutional Constraints to Growth Across South Asia. Enabling Agricultural Trade (EAT), United States Agency for International Development (USAID). 